\title{
A new catfish species of the genus Trichomycterus (Siluriformes: Trichomycteridae) from the río Orinoco versant of Páramo de Cruz Verde, Eastern Cordillera of Colombia
}

\author{
Carlos DoNascimientoํㅗㄴ Saúl Prada-Pedreros ${ }^{2}$ and Jürgen Guerrero-Kommritz ${ }^{3}$
}

\begin{abstract}
A new Trichomycterus is described from a highland tributary of the río Meta (Orinoco basin), along the east flank of Páramo de Cruz Verde, Eastern Cordillera of Colombia. The new species is distinguished from most of its congeners by having a reduced posterior cranial fontanel, restricted to the parieto-supraoccipital, cleithrum pierced by several foramina, and an unique combination of four irregular rows of conic teeth in premaxilla and dentary, 13-14 opercular odontodes, 41-43 interopercular odontodes, 6-7 branchiostegal rays, 40 or 41 free vertebrae, 14-18 ribs, first ray of pectoral fin slightly projected as a short filament, 7-8 branched pectoral-fin rays, dorsal-fin origin at same level of pelvic-fin insertion, anal-fin origin posterior to dorsal-fin base, caudal-fin margin slightly rounded, a single upper hypural plate $(3+4+5)$, and coloration pattern consisting in ground color dark brown with a thin mid-lateral dark stripe. Phylogenetic relationships of the new species based on the shared presence of derived features related to posterior cranial fontanel and cleithrum are discussed. The new species is also compared to the only two described species from Andean tributaries of río Orinoco basin.
\end{abstract}

É descrita uma espécie nova de Trichomycterus de um pequeno tributário dos Andes da bacia do río Meta (bacia do río Orinoco), no flanco oriental do Páramo de Cruz Verde na Cordilhera Oriental da Colômbia. A espécie nova distingue-se da maioria de seus congêneres por apresentar uma fontanela craniana posterior reduzida, restrita ao parieto-supraoccipital, cleitro perfurado por vários forames e uma combinação única de quatro fileiras irregulares de dentes cónicos no pré-maxilar e no dentário, 13-14 odontódeos operculares, 41-43 odontódeos interoperculares, 6-7 raios branquiostégios, 40 ou 41 vértebras livres, 14-18 costelas, o primeiro raio da nadadeira peitoral ligeiramente projetado em um curto filamento, 7-8 raios ramificados na nadadeira peitoral, origem da nadadeira dorsal no mesmo nível de inserção das nadadeiras pélvicas, origem da nadadeira anal posterior à base da nadadeira dorsal, margem da nadadeira caudal ligeiramente arredondada, uma única placa hipural superior $(3+4+5)$ e padrão de coloração em um fundo de cor marrom escuro com uma fina listra escura média lateral. As relações filogenéticas da espécie nova com base na presença compartilhada de caracteres derivados relacionados com a fontanela craniana posterior e o cleitro são discutidas. A espécie nova também é comparada com as duas únicas espécies descritas de afluentes dos Andes da bacia do río Orinoco.

Key words: Ituglanis, río Orinoco basin, Osteology, Trichomycterinae, Trichomycterus cachiraensis.

\section{Introduction}

The genus Trichomycterus Valenciennes, 1832, currently comprises 163 valid species (Eschmeyer, 2014), from which 27 species have been described from Colombia, excedeed only by Brazil, with 82 species. The geographic distribution of the Colombian species reflects a clear prevalence in the
trans-Andean drainages: río Magdalena basin (15 species), río San Juan basin (4 species), ríos Cauca and Sinú basins (each with 2 species), and río Catatumbo basin (1 species); when compared to cis-Andean region: only two species described from Orinoco basin, and none described or even recorded from Amazon basin (Castellanos-Morales \& Galvis, 2012). This situation might be an artificial bias, as a

\footnotetext{
${ }^{1}$ Departamento de Biología / Museo de Zoología de la Universidad de Carabobo, Facultad Experimental de Ciencias y Tecnología, Universidad de Carabobo, Valencia 2005, Venezuela. cdonascimiento@uc.edu.ve

${ }^{2}$ Unidad de Ecología y Sistemática, Departamento de Biología, Pontificia Universidad Javeriana, Cra. 7 n 40-82, Bogotá, Colombia. saul. prada@javeriana.edu.co

${ }^{3}$ Zoologisches Museum der Universität Hamburg, Martin-Luther-King-Platz 3, D-20146 Hamburg, Germany. greledone@hotmail.com
} 
result of the historically and still more numerous collecting efforts carried out in the more populated and accessible trans-Andean region, as was already noted and discussed in some detail by Maldonado-Ocampo et al. (2009).

Albeit the remarkable taxonomic diversity of the genus keeps increasing, especially as a result of ichthyological surveys conducted in previously unexplored areas, the phylogenetic relationships of its constituting species and systematic position of Trichomycterus in the family have not been comprehensively evaluated. A few proposals of smaller putative monophyletic units within the genus (e.g., Trichomycterus brasiliensis species-group), have been recently advanced (Barbosa \& Costa, 2003a; Fernández \& Osinaga, 2006; Wosiacki \& de Pinna, 2008), and all of these species groups are circumscribed to specific restricted geographic regions. This situation is understandable given the challenging taxonomic history of Trichomycterus, involving many species defined by brief and poorly informative descriptions, and old preserved associated type material, limiting not only the availability of complete morphological information but even the applicability of those names to any other specimen than the types. In fact, the monophyletic status of Trichomycterus has been questioned by several authors (Baskin, 1973; de Pinna, 1989; Costa \& Bockmann, 1993), so that the genus stands up to date as a non-diagnosable taxon, where all generalized forms not fitting in remaining trichomycterid genera are placed.

An assessment project of the conservation status of Trichomycterus venulosus conducted between 2004 and 2005 , resulted in the collection of specimens from a different trichomycterid species in the Páramo de Cruz Verde, Eastern Cordillera of Colombia, in the flank draining to the río Orinoco basin. These specimens are assignable to the genus Trichomycterus, and exhibit a suite of uncommon apomorphic characters plus an unique combination of other features that do not fit with morphological patterns of described species of that genus, hence this species is formally described here and its phylogenetic affinities are discussed.

\section{Material and Methods}

Morphometric data were taken point-to-point with digital calipers on the left side of specimens to the nearest $0.1 \mathrm{~mm}$. Methodology and terminology for measurements and counts follow de Pinna (1992a), with the addition of: 1) length of first and second pectoral-fin rays, 2) eye diameter (horizontal length of eye), and 3) interopercular patch length (taken from base of anterior most odontode to distal tip of posterior most odontode. Osteological terminology follows Bockman et al. (2004), except for the lachrymal-antorbital, which follows Schaefer (2003). Nomenclature of sensory pores of supraorbital and infraorbital canals followed Arratia \& Huaquin (1995), and terminology and homologies for postotic branches follow Schaefer \& Aquino (2000). Counts for the holotype in variable meristics are indicated by an asterisk or enclosed in parentheses. Numbers of opercular and interopercular odontodes and pharyngeal teeth are based on cleared and stained (CS) paratype specimens, prepared following the procedure of Taylor \& Van Dyke (1985). Data on number of branchiostegal rays, vertebrae, ribs, fin rays, number and position of supporting elements of dorsal and anal fins, and other osteological features were obtained from CS paratype specimens and radiographs of the holotype and remaining paratypes at MPUJ (11 specimens). Vertebral counts include only free vertebrae (posterior to Weberian complex), and the compound caudal centrum (PU1+U1) was counted as one element (Lundberg \& Baskin, 1969). Morphological data for T. migrans (Dahl, 1960) are based on original description, and photographs of holotype, available at the All Catfish Species Inventory (ACSI) Image Base website (Morris et al., 2006). Osteological data of FMNH primary types of Ituglanis and Trichomycterus nominal species were obtained through X-ray images, also available at the ACSI Image Base website. Osteological information of Nematogenys inermis (Guichenot, 1848) was based on CT-scan images and animations available at the Catfish Bones: The Digital Atlas of Catfish Morphology website (http://catfishbone.acnatsci.org/). Abbreviations: HL, head length; PU, preural vertebral centrum; SL, standard length; U, ural vertebral centrum. Institutional abbreviations follow Leviton et al. (1985), with the addition of CZUT-IC, Colección Zoológica Universidad del Tolima, Ictiología, Ibagué, Colombia; IAvH-P, Colección de Peces Dulceacuícolas, Instituto Alexander von Humboldt, Villa de Leyva, Colombia; IMCN, Colección Zoológica de Referencia del Museo de Ciencias Naturales Federico Carlos Lehmann Valencia del INCIVA, Cali, Colombia; MBUCVCT, Colección de Transparencias de Peces del Museo de Biología de la Universidad Central de Venezuela, Caracas, Venezuela; MHNLS, Museo de Historia Natural La Salle, Caracas, Venezuela, MPUJ, Museo Javeriano de Historia Natural "Lorenzo Uribe S. J. ”, Bogotá, Colombia.

\section{Results}

\section{Trichomycterus steindachneri, new species}

Figs. 1a, 2a, 3a, 4-5

Holotype. MPUJ 4191, $143.5 \mathrm{~mm}$ SL, Colombia, Cundinamarca, Ubaque, vereda Pueblo Nuevo, quebrada El Charco, tributary of quebrada Santa Bárbara, río El Palmar system, río Orinoco basin, 04³1'10.3”N 7358'44.6”W, 2700 m, 19 Aug 2005, S. Prada-Pedreros, C. Rivera \& W. Vanegas.

Paratypes. MBUCV-V-35652 (ex MPUJ 2487), 2, 86.7$88.8 \mathrm{~mm}$ SL (MBUCV-CT-1047, 1 CS, $86.7 \mathrm{~mm} \mathrm{SL}$ ), MPUJ 2491, 2, 74.2-77.1 mm SL, same data as holotype, but collected on 20 Aug 2005. MPUJ 2482, 9, 81.1-120.5 mm SL (MBUCV-CT-1053, 3 CS, specimens 2 \& 6 completely disarticulated: $105.7-123.9 \mathrm{~mm}$ SL, specimen 5 entire: 106.8 $\mathrm{mm} \mathrm{SL}$ ), collected with the holotype. 
Diagnosis. Trichomycterus steindachneri is distinguished from most Trichomycterus species (except T. cachiraensis Ardila Rodríguez, 2008) by having several broad foramina on cleithrum lamina (Fig. 1a) (vs. cleithrum not pierced). The new species is also distinguishable from most congeners except $T$. cachiraensis and $T$. brachykechenos Ferrer \& Malabarba, 2013 by having a small posterior cranial fontanel (Fig. 2a), restricted to the parieto-supraoccipital ( $v s$. a long somewhat rectangular fontanel extending anteriorly between frontal bones and posteriorly into anteromedian region of parietosupraoccipital). Trichomycterus steindachneri differs from $T$. cachiraensis by having 40 or 41 free vertebrae (vs. 37-39), 14-18 ribs (vs. 12), a single upper hypural plate: $3+4+5$ (Fig. 3a) (vs. two hypural plates: 3,4+5, Fig. $3 \mathrm{~b}$ ), and by its coloration pattern (ground color dark brown with a thin mid-lateral dark stripe $v s$. ground color light brown with three lateral rows of small dark spots). Trichomycterus steindachneri can be distinguished from T. brachykechenos by having four rows of premaxillary and dentary teeth (vs. three), 13-14 opercular odontodes (vs. 8-11), 41-43 interopercular odontodes (vs. 22-30), 6-7 branchiostegal rays ( $v s .8$ ), anterior portion of sphenotic anterolaterally directed in dorsal view (vs. directed anteriorly), autopalatine with mesial margin straight (vs. concave), 12-16 teeth on ceratobranchial 5 (vs. 2122 ), 11-14 teeth on upper dentigerous plate (vs. 22-25), infraorbital sensory pores i1 and i3 present ( $v s$. absent), 40 or 41 free vertebrae (vs. 37 or 38), 14-18 ribs (vs. 12), first ray of pectoral fin slightly projected as a short filament (Figs. 4-5) (vs. not prolonged as a filament), 7-8 branched pectoral-fin rays (vs. 5-6), dorsal-fin origin at same level of pelvic-fin insertion (vs. at vertical through last third of pelvic fin), anal-fin origin posterior to dorsal-fin base (vs. at vertical through middle of dorsal-fin base), anal fin with seven basal radials (vs. six), procurrent caudal-fin rays 16-21 dorsally and 14-17 ventrally (vs. 15-16 and $10-13$, respectively), and by the color pattern of lateral surface of body consisting in background dark brown with a thin mid-lateral dark stripe (vs. background light yellow with superficial layer of densely mottled dark brown). Trichomycterus steindachneri is further distinguished from T. dorsostriatus (Eigenmann, 1918), which also occurs in the río Meta system, by having 40 or 41 free vertebrae (vs. 37), dorsal fin inserted just posterior to neural spine of vertebrae 18 or 19 ( $v s$. vertebra 16), analfin origin behind posterior end of dorsal-fin base, inserted just posterior to hemal spine of vertebrae 22-24 (vs. under posterior portion of dorsal-fin base, just posterior to vertebra 20), a single upper hypural plate (vs. two upper hypural plates), and by the color pattern consisting in a thin mid-lateral dark stripe ( $v s$. a dark band or row of spots from just above the gill-opening to the base of the upper caudal-fin rays). Trichomycterus steindachneri can also be differentiated from the only other species described from western tributaries of the Orinoco in
Colombia, T. migrans (río Guaviare system), by its maxillary barbel extending beyond pectoral-fin origin (vs. scarcely reaching this point), anal-fin origin entirely behind dorsal-fin base ( $v s$. at vertical through base of last dorsal-fin ray), and caudal-fin margin slightly rounded ( $v s$. deeply emarginated). Trichomycterus steindachneri can be readily differentiated from remaining congeners described or recorded from Colombia (except T. retropinnis Regan, 1903 ) by its relatively rare pigmentation pattern consisting in background dark brown with a single thin dark stripe along middle of side of body ( $v s$. background light; either plain, with more than one stripe on lateral surface of body, with a single but wide mid-lateral band, or variably spotted or dotted). Trichomycterus steindachneri differs from $T$. retropinnis by having first pectoral-fin ray slightly projected beyond margin of fin as a short filament of less than $20 \%$ length of adjacent branched ray ( $v s$. projecting as a long filament of $c a .40 \%$ length of adjacent branched ray), 7-8 branched pectoral-fin rays ( $v s .6$ branched rays), pelvic fin covering anus ( $v s$. not reaching anus), relative position of the dorsal fin, expressed as dorsal-fin origin at same level of pelvic-fin insertion ( $v s$. dorsal-fin origin behind distal margin of pelvic fin), and anal-fin origin entirely behind of dorsal-fin base ( $v s$. anal-fin origin under anterior third of dorsal-fin base).
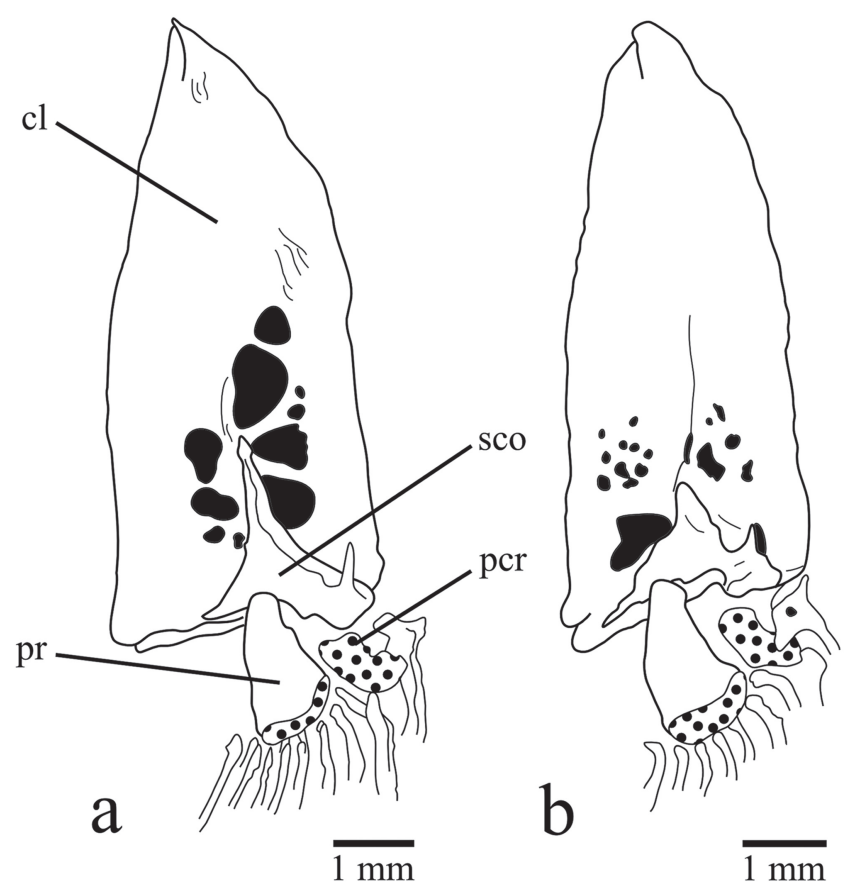

Fig. 1. Pectoral girdle of: a. Trichomycterus steindachneri (MBUCV-V-35652), paratype, $86.7 \mathrm{~mm}$ SL. b. $T$. cachiraensis (MBUCV-V-35384), paratype, $74.9 \mathrm{~mm}$ SL. Ventral view. Abbreviations: cl, cleithrum; pcr, pectoral complex radial; pr, pectoral radial; sco, scapulocoracoid. 


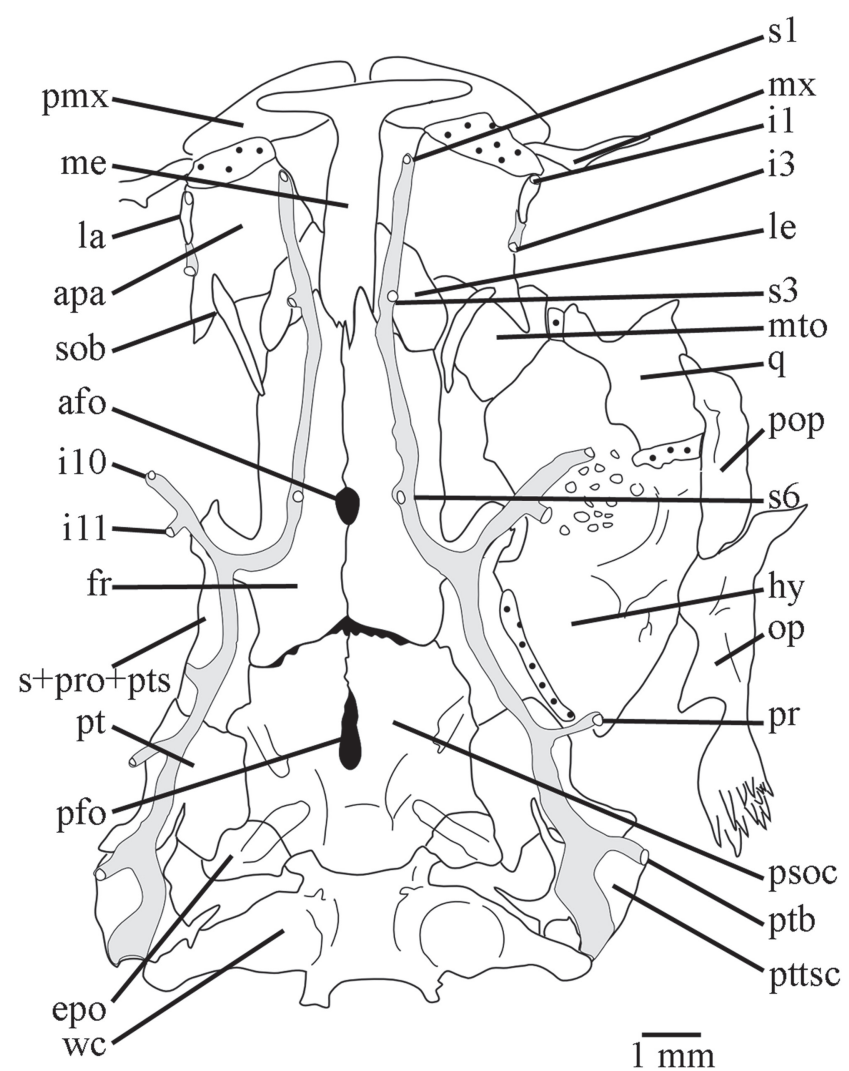

a

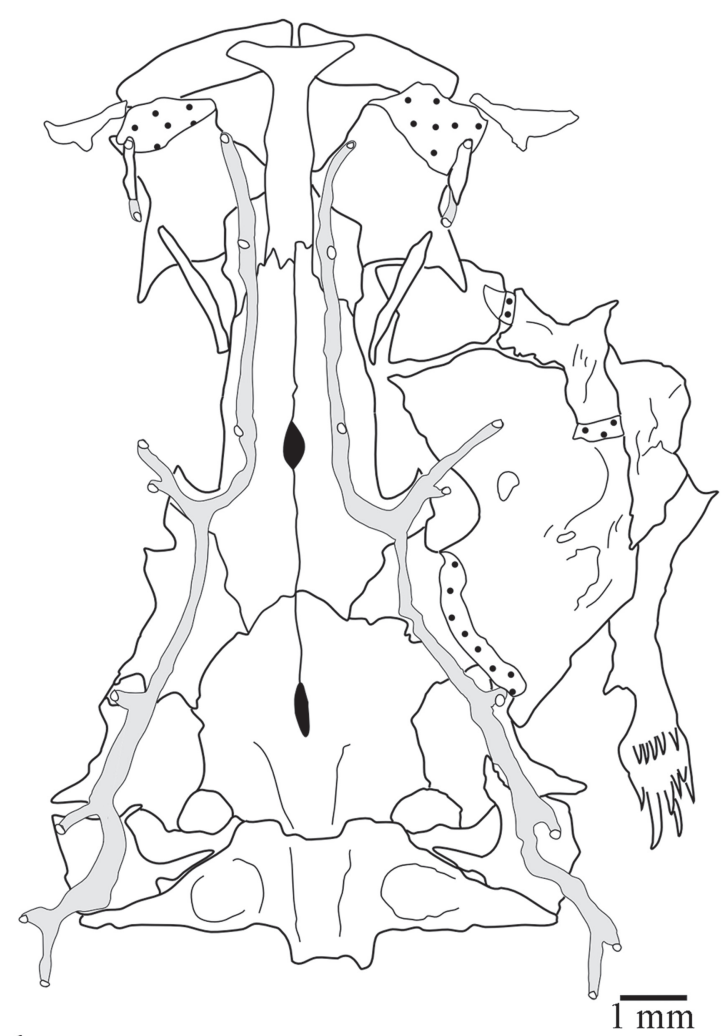

b

Fig. 2. Neurocranium, Weberian complex, and right suspensorium and opercular series of: a. Trichomycterus steindachneri (MBUCV-V-35652), paratype, 86.7 mm SL. b. T. cachiraensis (MBUCV-V-35384), paratype, $74.9 \mathrm{~mm}$ SL. Dorsal view. Abbreviations: afo, anterior fontanel; apa, autopalatine; epo, epioccipital; fr, frontal; la, lachrymal-antorbital; le, lateral ethmoid; hy, hyomandibula; i1, infraorbital sensory pore 1 ; i3, infraorbital sensory pore 3 ; i10-11, infraorbital sensory pores 10 and 11 ; me, mesethmoid; mto, metapterygoid; mx, maxilla; op, opercle; pfo, posterior fontanel; pmx, premaxilla; pop, preopercle; pr, preopercular sensory pore; psoc, parieto-supraoccipital; pt, pterotic; ptb, pterotic branch; pttsc, posttemporo-supracleithrum; q, quadrate; s1, supraorbital sensory pore 1; s3, supraorbital sensory pore 3; s6, supraorbital sensory pore 6 (epiphyseal branch); sob, sesamoid supraorbital; sp+pro+pts, sphenotic-prootic-pterosphenoid complex bone; wc, Weberian capsule.

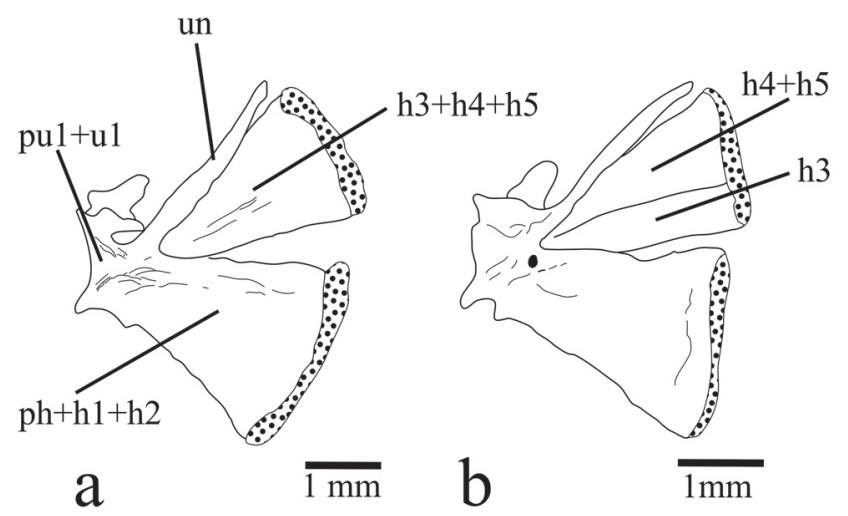

Fig. 3. Caudal skeleton (caudal-fin rays not illustrated) of: a. Trichomycterus steindachneri (MBUCV-V-35652), paratype, $86.7 \mathrm{~mm}$ SL. b. T. cachiraensis (MBUCV-V-35384), paratype, $74.9 \mathrm{~mm}$ SL. Left lateral view. Abbreviations: h1-5, hypurals 1 to 5 ; ph, parhypural; pu1+u1, compound caudal centrum (preural centrum 1 plus ural centrum 1); un, uroneural.
Description. Morphometric data presented in Table 1. Body elongated, depressed in anterior region of trunk and becoming gradually compressed to caudal-fin base. Dorsal and ventral profiles straight and parallel, sloping dorsally and ventrally just posterior to dorsal and anal-fin bases, respectively (Figs. 4-5). Cross-section of body elliptical at pectoral-fin insertion with longest axis along horizontal plane.

Head depressed, nearly as long as wide, parabolic in dorsal view in specimens shorter than $90 \mathrm{~mm}$ SL and square in larger specimens. Lateral portion of head of large specimens (90 mm SL or more) swollen by well-developed jaw muscles, resulting in square aspect of head in dorsal view. Eye small, located dorsolateral, approximately on middle of head length. Eye rim not free, skin covering eye continuous with head skin. Mouth subterminal. Lateral fleshy lobe of lower lip scarcely conspicuous as thickening of lateral portion of lip. Premaxilla with four irregular rows of conical teeth. Dentary with four irregular rows of teeth, similar to those of premaxilla. Anterior nostril small, surrounded by 
low fleshy thin flap, posterolaterally continuous with nasal barbel. Posterior nostril adjacent to anterior nostril; anterior rim thick, not delimited by fleshy elevated margin; posterior rim not delimited by fleshy flap, and continuous with head surface. Barbels dorsoventrally flattened and tapered distally. Nasal barbel originating from posterolateral margin of anterior nostril, and reaching origin of opercular patch of odontodes. Maxillary barbel extending slightly beyond pectoral-fin origin. Rictal barbel extending to anterior third of interopercular patch of odontodes. Interopercular patch with 41-43 odontodes and 21-23 replacement odontodes, arranged in three irregular rows. Posterior interopercular odontodes of medial row largest. Opercle with 13 or 14 odontodes and 6 or 7 replacement odontodes, approximately disposed in five anteroposterior irregular rows. Posterior most opercular odontodes largest. Branchial membrane free from ishtmus, except anteriorly, and supported by $6^{*}$ or 7 branchiostegal rays. Branchiostegal rays 3 or 4 to lateral most, distally expanded. Branchiostegal ray 4 or 5 with greatest distal expansion.

Anterior margin of mesethmoid cornua straight (Fig. 2a). Anterior fontanel small oval opening just anterior to epiphyseal bar, at level of exit of infraorbital canal from neurocranium. Lachrymal-antorbital associated with anterior section of infraorbital canal (sensory pores il and i3). Sesamoid supraorbital long straight rod, without lateral processes. Lateral processes of frontal and sphenotic, where infraorbital canal leaves neurocranium, forming conspicuous lateral tube anterolaterally projected. Posterior fontanel short, two times of anterior fontanel length, oval in shape, and placed entirely on parieto-supraoccipital, but continuous with anterior sagittal suture connecting frontal bones medially. Posttemporo-supracleithrum with long and pointed medial process, extending parallel to anterior margin of Weberian capsule, approaching to basi-exoccipital. Vomer arrow-head shaped, with conspicuous lateral processes posterolaterally directed and long posterior process inserted into anterior process of parasphenoid. Posterior process of parasphenoid long and extending over anterior portion of basi-exoccipital, laterally bordered by two anterior membranous processes of basi-exoccipital. Lateral opening of Weberian capsule at tip of lateral tubular projection, around same length of diameter of capsule. Premaxilla rectangular in shape. Maxilla boomerang shaped, shorter than premaxilla. Articular facet of autopalatine for lateral ethmoid on medial margin of bone, just at posteromedial corner. Anteromedial corner of autopalatine in contact with lateral margin of lateral process of vomer. Metapterygoid laminar and triangular in shape. Hyomandibula articulating anteriorly through dorsoanterior membranous outgrowth with metapterygoid. Interopercular plate supporting odontodes, not extended anteriorly to articular facet for preopercle. Basibranchials 2 and 3 and hypobranchial 1 approximately of same length. Anterolateral process of ossified portion of hypobranchial 3 longer than that of hypobranchial 2. Ceratobranchial 3 with broad notch at proximal portion of posterior margin. Ceratobranchial 5 with 12-16 conical teeth, along anterior portion of medial margin, arranged in two irregular rows. Largest teeth posterolaterally placed. Pharyngobranchial 3 with medial process in posterior tip and broad laminar expansion along medial margin. Upper dentigerous plate with conical teeth arranged in two rows. External row restricted to anterior portion, with 2-4 teeth. Internal row complete, along entire medial margin of plate, with 9-10 teeth. Teeth of internal row larger than those of external row.

Supraorbital sensory canal continuous with three pores, and not connected to its counterpart through medial commissure. Sensory pore s1 medially adjacent to anterior nostril. s3 medial to posterior nostril. s6 (epiphyseal) paired, at level of posterior eye rim. Infraorbital sensory canal interrupted in two portions; anterior most portion with sensory pores i1 and i3, laterally adjacent to anterior and posterior nostrils, respectively; posterior most portion connected to supraorbital and otic canals, with sensory pore i10, adjacent to ventroposterior eye rim; i11 posterior to eye at horizontal level of dorsal eye rim. Preopercular canal short with single terminal pore above origin of opercular patch of odontodes. Postotic canal with single pterotic branch and associated pore above opercular patch of odontodes. Lateral line canal very short with two pores above pectoral-fin base. Sensory pore 111 ventral to main lateral line canal and 112 terminus of main lateral line canal.

Precaudal free vertebrae 9-13 (10) and caudal vertebrae 27-32 (31), totaling 40 or $41 *$ vertebrae. Ribs $14-18^{*}$ (one CS specimen with one posterior accessory short rib of similar size of penultimate rib, on left side of last supporting rib vertebra). Penultimate rib shortest, around one third of last rib length. First hemal spine on vertebra 16-19 (18). Anus at vertical through anterior third of dorsal-fin base.

Pectoral fin with $1,7-8^{*}$ rays. First ray longest, slightly projected beyond margin of fin as short filament. Pectoral complex radial completely cartilaginous (Fig. 1a). Scapulocoracoid anterior process long and pointed. Cleithrum with broad foramina under scapulocoracoid and adjacent to hypocoracoid portion.

Pelvic fin with i,4 rays, and lateral splint, its length around half of first ray length. First ray shortest and third ray longest. Inner margins of pelvic-fin bases close to each other. Posterior margin of fin covering anus. Basipterygium with two anterior long processes of around same length or medial process slightly longer.

Dorsal fin with 2-4 (3) procurrent rays and ii, 7 principal rays. Shape of fin rectangular in lateral view, posterior margin truncated. Second branched ray longest. Origin of fin at same level of pelvic-fin insertion, at middle of body (including caudal fin). Basal and anterior portions of fin extensively covered by thick integument, anterior most rays (procurrent and unbranched), hardly visible externally. Supporting elements of dorsal fin represented by eight basal radials, inserted between neural spines of vertebrae 18-23, 18-24, or 19-24*, and seven distal radials (last distal radial cartilaginous), associated with second to last basal radials. 


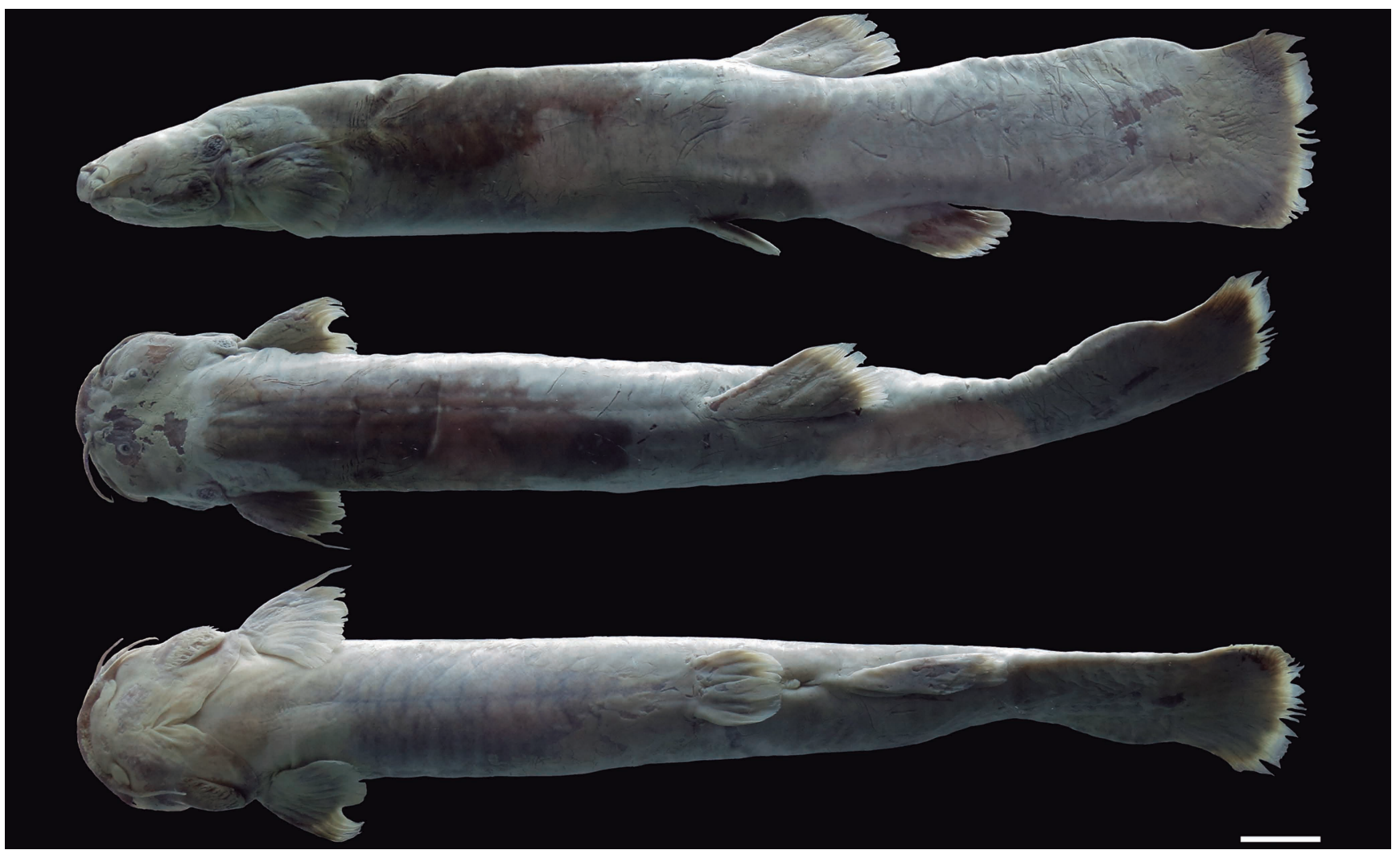

Fig. 4. Trichomycterus steindachneri, holotype, MPUJ 4191, $143.5 \mathrm{~mm}$ SL; Colombia, Cundinamarca, Ubaque, vereda Pueblo Nuevo, quebrada El Charco, tributary of quebrada Santa Bárbara, río El Palmar system, río Orinoco basin, 04³1'10.3”N $73^{\circ} 58^{\prime} 44.6 ” \mathrm{~W}, 2700 \mathrm{~m}$. Scale bar $=1 \mathrm{~cm}$.

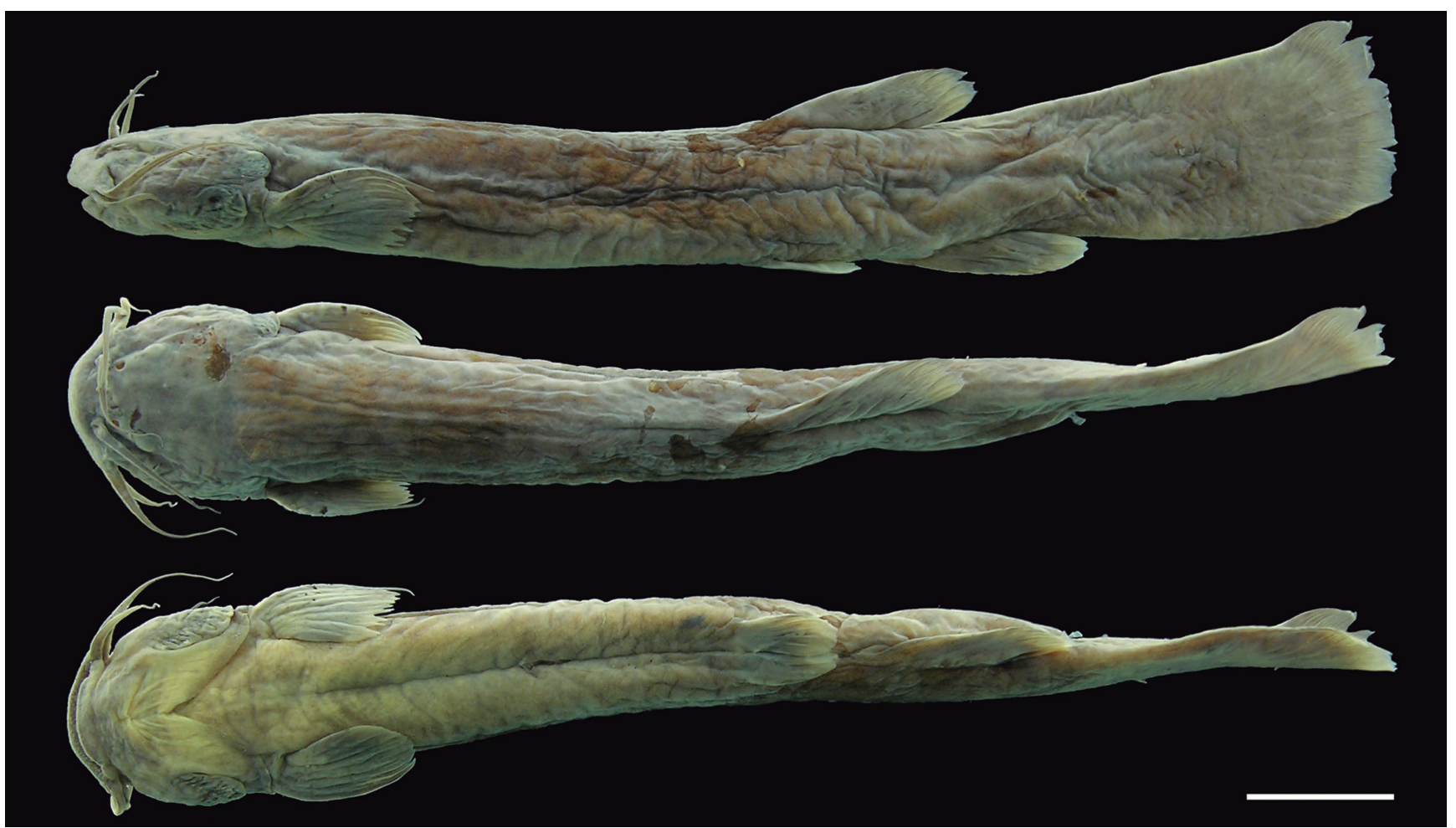

Fig. 5. Trichomycterus steindachneri, paratype, MBUCV-V-35652, $88.8 \mathrm{~mm}$ SL, Colombia, Cundinamarca, Ubaque, Vereda Pueblo Nuevo, quebrada El Charco, tributary of quebrada Santa Bárbara, río El Palmar system, río Orinoco basin. $04^{\circ} 31^{\prime} 10.3^{\prime} \mathrm{N} 73^{\circ} 58^{\prime} 44.6^{\prime \prime} \mathrm{W}, 2700 \mathrm{~m}$. Scale bar $=1 \mathrm{~cm}$. 
Anal fin with $3 *-5$ procurrent rays and ii, $5 *$ or 6 principal rays. Anal fin similar in size and shape to dorsal fin. Second branched ray longest. Origin of fin entirely behind of dorsalfin base. Base and anterior portion of fin similarly covered by thick integument as in dorsal fin. Basal radials seven (MPUJ 2482 paratype specimen of $105.1 \mathrm{~mm} \mathrm{SL}$ with six basal radials), inserted between hemal spines of vertebrae 22-26, 23-27, 23-28, or 24-28*. Distal radials six, associated with first to penultimate basal radials. First distal radial entirely cartilaginous.

Caudal-fin margin slightly rounded. Caudal fin with i, $5+6$, i principal rays. Dorsal procurrent rays $16-21^{*}$, inserted posterior to neural spine of vertebra PU7-PU10*. Ventral procurrent rays $14-17^{*}$, inserted posterior to hemal spine of vertebra PU8-PU10*. Caudal skeleton with two similar plates (Fig. 3a), ventral plate represented by parhypural fused to hypurals $1+2$ and dorsal plate by hypurals $3+4+5$. Epural absent. Neural spine of preural centrum 1 complete with conspicuous anterior and posterior processes at base of spine.

Table 1. Morphometric data for holotype $(\mathrm{H})$ and 11 paratypes of Trichomycterus steindachneri. Standard length (SL) expressed in mm. Measurements expressed as percents of SL or head length (HL). M: mean; R: range; SD: standard deviation.

\begin{tabular}{lcccc}
\hline & $\mathrm{H}$ & $\mathrm{M}$ & $\mathrm{R}$ & $\mathrm{SD}$ \\
\hline Standard length & 147.0 & - & $74.2-147.0$ & - \\
& Percents of standard length & & \\
Total length & 109.2 & 112.4 & $109.2-113.7$ & - \\
Body depth & 12.8 & 14.0 & $11.2-15.4$ & 1.4 \\
First pectoral-fin ray & 11.7 & 12.2 & $9.8-13.3$ & 1.0 \\
Second pectoral-fin ray & 10.0 & 10.2 & $9.1-11.1$ & 0.6 \\
Predorsal length & 57.5 & 60.5 & $57.5-63.4$ & 1.7 \\
Preanal length & 65.6 & 69.2 & $65.6-73.3$ & 2.1 \\
Prepelvic length & 53.9 & 57.0 & $53.9-58.7$ & 1.5 \\
Dorsal fin base & 10.1 & 11.6 & $10.1-12.8$ & 0.7 \\
Anal fin base & 8.7 & 9.9 & $8.7-10.7$ & 0.6 \\
Caudal-peduncle length & 22.5 & 20.7 & $19.5-22.5$ & 0.9 \\
Caudal-peduncle depth & 12.6 & 11.7 & $9.6-13.0$ & 1.0 \\
Head length & 15.0 & 16.6 & $15.0-17.8$ & 0.9 \\
& 107.7 & 102.3 & $97.0-117.1$ & 5.9 \\
Head width & 57.0 & 59.4 & $51.5-69.1$ & 5.6 \\
Head depth & 51.6 & 43.4 & $37.9-51.6$ & 4.0 \\
Snout length & 56.6 & 49.7 & $43.9-56.6$ & 3.8 \\
Mouth width & 39.8 & 37.3 & $31.1-40.6$ & 3.1 \\
Interorbital distance & 6.3 & 7.8 & $6.3-9.1$ & 0.7 \\
Eye diameter & 48.4 & 67.3 & $48.4-81.2$ & 10.0 \\
Maxillary barbel length & 56.1 & 62.5 & $55.3-70.1$ & 4.6 \\
Nasal barbel length & 48.4 & 60.1 & $48.4-72.2$ & 5.7 \\
Rictal barbel length & 16.7 & 14.7 & $9.0-19.3$ & 2.9 \\
Interopercular patch length & & & &
\end{tabular}

Color in alcohol. Ground color uniformly dark brown on lateral and dorsal surfaces of head and body, including barbels, lower lip, ventral surface of head anterior to gular apex and interopercular patch of odontodes. Ventral surface of branchiostegal membrane and small triangular area delimited anteriorly by gular apex, cream. Ventral surface of body from pectoral region to pelvic-fin insertion cream to light brown, becoming darker posteriorly. Trunk with thin and dark, mid-lateral stripe, extending posterior to opercular patch of odontodes to region below dorsal fin, fading posterior to this point. Some chromatophores clustered along ventrolateral row originating above pelvic-fin insertion to anterior portion of anal-fin base. Few chromatophores forming diffuse blotches, along dorsolateral row, anterior to dorsalfin insertion. Both dorsal and ventral surfaces of pectoral and pelvic fins, pigmented as body, except distal margin. First pectoral-fin ray, basal portion of remaining rays, and basal portion of interradial membrane densely pigmented. Distal tip of fin rays light. Anterior two thirds of rays and interradial membrane of pelvic fin darkly pigmented and distal margin light. Basal integument layer of dorsal and anal fins, including basal portion of rays and interradial membrane, pigmented as body, and distal margin hyaline. Basal portion of caudal fin darkly pigmented. Darkest semicircular halo preceding hyaline distal margin of caudal fin.

Distribution and habitat. Trichomycterus steindachneri is known from quebrada El Charco, a tributary of quebrada Santa Bárbara, which drains the east flank of the Eastern Cordillera of Colombian Andes, to empties into río El Palmar of the río Meta drainage, río Orinoco basin (Fig. 6). The collecting site is a typical lotic environment of high altitude $(2700 \mathrm{~m})$, about $50 \mathrm{~cm}$ wide, with small pools and falls (not higher than $40 \mathrm{~cm}$ ). Stream banks had dense riparian vegetation, constituted by shrubs and grasses, and dominated by the chusque (Chusquea scandens). Other marginal sections were only covered with pasture.

Etymology. The specific epithet steindachneri (adjective genitive masculine singular) is a patronym honoring the prominent Austrian zoologist Franz Steindachner (18341919), in recognition of his dedicated life and significant work in documenting the fish biodiversity, especially that from South America. His profuse morphological descriptions mainly contributed to settle the current standard in ichthyological taxonomic works.

\section{Discussion}

The confident assertion of internal features as phylogenetically informative characters for Trichomycterus has as major impediment the lack of pertinent information in the vast majority of its constituting species. However in those species whose anatomy has been studied in some detail - e.g., Trichomycterus boylei Nichols, 1956, T. duellmani and T. roigi Arratia \& Menu-Marque, 1984 in Arratia \& Menu-Marque, 1984; T. areolatus Valenciennes, 1846, T. nigricans Valenciennes, 1832 (type-species of the genus), T. punctulatus Valenciennes, 1846 and T. rivulatus Valenciennes, 1846 (also as T. gracilis Valenciennes, 1846) 

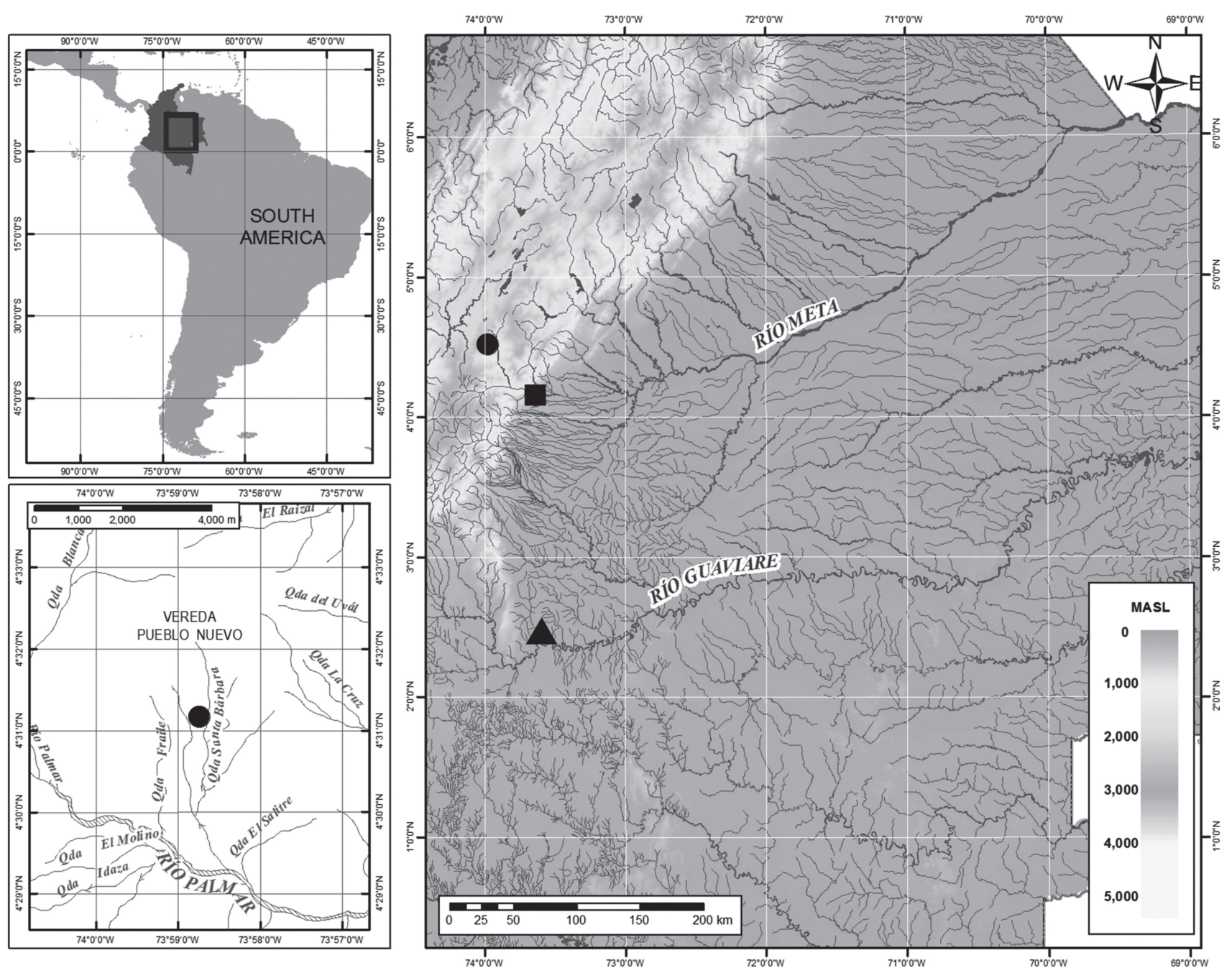

Fig. 6. Map of Middle Eastern region of Colombia showing the geographic distribution of Trichomycterus steindachneri (circle): Cundinamarca, Ubaque, vereda Pueblo Nuevo, quebrada El Charco, 04³1'10.3”' $73^{\circ} 58^{\prime} 44.6^{\prime \prime} \mathrm{W}$, T. dorsostriatus (square): Meta, Villavicencio, $04^{\circ} 09^{\prime} 12^{\prime \prime} \mathrm{N} 73^{\circ} 38^{\prime} 06^{\prime} \mathrm{W}$ and T. migrans (triangle): Meta, Serranía La Macarena, tributary creek of río Guayabero, $02^{\circ} 28^{\prime} 21^{\prime \prime} \mathrm{N} 73^{\circ} 35^{\prime} 43^{\prime \prime} \mathrm{W}$. Inset at lower left corner corresponds to enlargment of distribution region of T. steindachneri.

in Arratia, 1998; T. guianensis (Eigenmann, 1909) and T. punctulatus in Adriaens et al., 2010; T. candidus (Miranda Ribeiro, 1949) in Barbosa \& Costa, 2003b; and T. potschi Barbosa \& Costa, 2003, T. celsae and T. lewi Lasso \& Provenzano, 2003, T. maracaya Bockmann \& Sazima, 2004, T. diabolus Bockmann, Casatti \& de Pinna, 2004, T. pradensis Sarmento-Soares, Martins-Pinheiro, Aranda \& Chamon, 2005, T. uisae Castellanos-Morales, 2008, T. payaya Sarmento-Soares, Zanata \& Martins-Pinheiro, 2011, T. dali Rizzato, Costa-Jr., Trajano \& Bichuette, 2011, T. rubbioli Bichuette \& Rizzato, 2012, T. argos Queiroz Lezama, Triques \& Santos, 2012, and T. balios, T. diatropoporos and T. poikilos Ferrer \& Malabarba, 2013, in their respective original descriptions - it is noteworthy a highly conservative pattern in their cranial morphology, allowing the identification of some evident variations to this pattern as potentially derived conditions to advance hypotheses of phylogenetic affinities for less inclusive groups. Ardila Rodríguez (2008) diagnosed his newly described species, $T$. cachiraensis, based on the presence of a reduced posterior cranial fontanel entirely located on the parieto-supraoccipital, although no comment was provided about the systematic significance of this character neither its taxonomic distribution in Trichomycteridae. The illustration provided in that same work (fig. 4: 37) for one CS paratype (CAR 97) shows a much reduced posterior fontanel isolated on the parieto-supraoccipital, a distinctive configuration that certainly represents an apomorphic condition, and identical to that described in some species formerly assigned to Trichomycterus, comprising now the genus Ituglanis Costa \& Bockmann, 1993. In fact, a reduced posterior fontanel restricted to the parieto-supraoccipital was originally proposed as a synapomorphy supporting Ituglanis (Costa \& Bockmann, 1993). Nevertheless, some variation has been 
verified also either in the degree of development of the fontanel (elongated), as well as in the existence of an anterior connection with the frontals through a mid-sagittal suture in T. cachiraensis (Fig. 2b). Except for only three known cases (T. megantoni Fernández \& Quispe Chuquihuamaní, 2007, T. sketi Castellanos-Morales, 2011, and T. brachykechenos), all remaining species of Trichomycterus whose neurocrania have been described and illustrated (e.g., T. taroba Wosiacki $\&$ Garavello, 2004) show a long roughly rectangular fontanel, extending anteriorly between the posterior part of the frontals, interrupting their midline articulation, and reaching posteriorly the center of the parieto-supraoccipital. This condition is also exhibited by the other genera traditionally assigned to Trichomycterinae (Eigenmann, 1918; Arratia, 1990, 1998; Arratia et al., 1978; Datovo \& Bockmann, 2010): Bullockia Arratia, Chang, Menu-Marque \& Rojas, 1978; Eremophilus Humboldt, 1805; Hatcheria Eigenmann, 1909; Rhizosomichthys Miles, 1943; Scleronema Eigenmann, 1918 and Silvinichthys Arratia, 1998 (pers. obs.; Arratia, 1998; Schaefer \& Fernández, 2009). A long rectangular fontanel has been verified also in Copionodontinae and Trichogenes Britski \& Ortega, 1983, both taxa being the sister group of remaining trichomycterids (Bichuette et al., 2008; de Pinna, 1992b, 1998; de Pinna et al., 2010), as well as in the sister group of Trichomycteridae, Nematogenys Girard, 1855 (pers. obs., Arratia Fuentes \& Chang Garrido, 1975; Baskin, 1973). Thus a long open fontanel extending anteriorly to the frontals constitutes the plesiomorphic state for trichomycterids. Trichomycterus megantoni shows a derived variation of the plesiomorphic pattern, represented by an extreme narrowing of the posterior fontanel (Fernández \& Quispe Chuquihuamaní, 2007). However this slit still extends to the epiphyseal bar, between the frontal bones, as in the plesiomorphic condition. Trichomycterus sketi has the posterior fontanel divided into two widely separated openings, located just after the epiphyseal bar and on the center of the parieto-supraoccipital, respectively, but yet connected by a mid-sagittal suture (Castellanos-Morales, 2011). On the other hand, T. brachykechenos was directly compared to T. megantoni, as having the same configuration of the fontanel (Ferrer \& Malabarba, 2013), though the illustration offered (Ferrer \& Malabarba, 2013: 220, fig. 2d), presents an elongated posterior fontanel entirely located on the parieto-supraoccipital, identical to the condition found in T. steindachneri (Fig. 2a), and also in at least one paratype specimen of $T$. cachiraensis (Fig. 2b). The conditions in $T$. megantoni and $T$. sketi seem to be successive intermediate derived states (states 1 and 2, respectively), in a morphocline continuing in a single restricted opening entirely located on the parieto-supraoccipital (T. brachykechenos, T. cachiraensis, and T. steindachneri), state 3 of the transformation series. A further reduction to a round orifice isolated on the parietosupraoccipital (i.e., lacking an anterior mid-sagittal suture that connects with the medial articulation between frontal bones), which distinguishes most Ituglanis species and at least some specimens of $T$. cachiraensis, would represent a more derived character state (state 4) of this morphocline. Thus $T$. cachiraensis would be polymorphic for character states 3 and 4 .

Ituglanis was hypothesized as the sister group of a clade comprising the subfamilies Tridentinae, Stegophilinae, Vandelliinae, Sarcoglanidinae, and Glanapteryginae (clade TSVSG) (Costa \& Bockmann, 1993; de Pinna, 1998). However, this hypothesis has been recently challenged on the basis of new evidence (myological characters) that supports a monophyletic Trichomycterinae (including Ituglanis and Scleronema), and the critical demonstration of the invalid or ambiguous nature of the purported synapomorphies supporting the closer relationships of Ituglanis to the clade TSVSG (Datovo \& Bockmann, 2010). Under this new concept of Trichomycterinae, phylogenetic position of Ituglanis remains unresolved, so a putative clade comprising Ituglanis, Trichomycterus brachykechenos, T. cachiraensis, and T. steindachneri, supported by the shared presence of a reduced posterior fontanel is a tenable working hypothesis. A possible relationship of Trichomycterus brachykechenos with Ituglanis was already advanced by Ferrer \& Malabarba (2013), based on the shared presence of reduction pattern of posterior fontanel, and anterior portion of sphenotic anteriorly directed. In fact, T. brachykechenos also shows a slightly concave medial margin of its autopalatine (Ferrer \& Malabarba 2013: 239, fig. 16). An autopalatine with a deep concavity on its medial margin was proposed as a synapomorphy for Ituglanis (Costa \& Bockmann, 1993). Therefore based on the character distribution above referred, Ituglanis would be redefined by two synapomorphies, namely, further reduction or absence of posterior fontanel, and medial margin of autopalatine deeply concave. This last character exhibits the plesiomorphic condition in $T$. cachiraensis and T. steindachneri (Fig. 2), whereas reduction and isolation of posterior fontanel is intraspecifically variable in T. cachiraensis. However, further investigation is required to determine if a reduced posterior fontanel is a valid synapomorphy for Ituglanis, T. brachykechenos, $T$. cachiraensis, and T. steindachneri or independently evolved in some components of this subset of Trichomycterinae. Furthermore, a sister group relationship of T. cachiraensis and T. steindachneri, is here proposed based on an apomorphic condition of the pectoral girdle, represented by the horizontal main laminar body of cleithrum pierced by several foramina, distributed under the scapulocoracoid and adjacent to the hipocoracoid portion (Fig. 1). Nonetheless, until a more comprehensive phylogenetic analysis of Trichomycterinae is available, we opt to defer any nomenclatural action involving the proposal of a new generic name to include T. cachiraensis and $T$. steindachneri, to recognize its putative sister group relationship with Ituglanis plus T. brachykechenos. Besides, given the absence of positive evidence (shared presence of synapomorphies diagnosing remaining trichomycterine genera), the less problematic generic allocation for the new species described here (T. steindachneri) and for $T$. cachiraensis, is precisely within Trichomycterus. 
The sister pair represented by Trichomycterus cachiraensis and T. steindachneri represents the first putative clade within the genus being separated by the Andean cordillera, thus bringing an additional trichomycterid clade besides Paravandellia Miranda Ribeiro, 1912 and Tridensimilis Schultz, 1944, with representatives in both sides of the Andes. These evidences further support the hyphothesis of a past biotic connection between the paleoAmazonas-Orinoco and central Colombia (currently drained by the río Magdalena) (Lundberg, 2005).

Comparative material. The same listed by DoNascimiento et al. (2014) and the following lots. Nematogenyidae: Nematogenys inermis: Chile: MBUCV-V-35727, 1, $166.3 \mathrm{~mm}$ SL. Trichomycteridae: Copionodontinae: Copionodon lianae: Brazil: Bahia: MBUCV-V-32262, 1, $63.8 \mathrm{~mm} \mathrm{SL}$, rio Piabas, Mucugê, 12 $57^{\prime} 00^{\prime \prime S} 16^{\circ} 39^{\prime} 00^{\prime \prime} \mathrm{W}$. Trichogeninae: Trichogenes longipinnis: Brazil: São Paulo: MHNLS 15888, 2, 38.9-35.7 mm SL (1 CS, $35.7 \mathrm{~mm} \mathrm{SL}$ ), Município de Ubatuba, Poço de Amor,

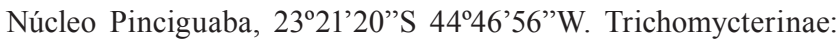
Bullockia maldonadoi: Chile: Bío-Bío: ANSP 180824, 3, 32.7$57.0 \mathrm{~mm}$ SL (1 CS, $50.7 \mathrm{~mm} \mathrm{SL}$ ), río Laja, $3 \mathrm{~km}$ below Salto Laja (río Bío Bío drainage). Hatcheria macraei: Argentina: Córdoba: MBUCV-V-32253, 2, 46.0-48.6 mm SL (1 CS, 46.0 mm SL), río Segundo, Pilar. Mendoza: MBUCV-V-32711, 3, 45.4-75.6 mm SL, río Grande. Ituglanis gracilior: Guyana: FMNH 53264, holotype of Pygidium gracilior Eigenmann, 1912, 18.4 mm SL, Erukin. Ituglanis herberti: Brazil: Rio Paraguay basin: Mato Grosso: MBUCV-V-32292, 1, $29.2 \mathrm{~mm} \mathrm{SL}$, riacho Anhuma, rio Verde de Mato Grosso, tributary of rio Negro, $19^{\circ} 9.69^{\prime} 00^{\prime \prime} \mathrm{S} 55^{\circ} 18^{\prime} 00^{\prime \prime} \mathrm{W}$. Ituglanis parahybae: Brazil: Parahyba: FMNH 58576, holotype of Pygidium proops parahybae Eigenmann, 1918, $28.3 \mathrm{~mm}$ SL, São João da Barra, Parahyba. Ituglanis sp: Venezuela: Río Orinoco basin: Apure: MBUCV-V-23550, 5, 36.0-40.9 mm SL (1 CS, $40.9 \mathrm{~mm} \mathrm{SL}$ ), río Claro, between Cunaviche and Capanaparo rivers, río Cunaviche drainage. Amazonas: MBUCV-V-24976, 6, 37.2-48.3 mm SL (1 CS, $43.5 \mathrm{~mm} \mathrm{SL}$ ), río Orinoco, in front of isla Cupoven. Rhizosomichthys totae: Colombia: Río Orinoco basin: Boyacá: MCZ 35744, paratype of Pygidium totae Miles, 1942, 1, $126.0 \mathrm{~mm} \mathrm{SL}$, Lago de Tota at head of río Upía (a tributary of río Meta), Eastern Cordillera, $05^{\circ} 35^{\prime} 00^{\prime \prime} \mathrm{N} 72^{\circ} 56^{\prime} 00^{\prime} \mathrm{W}, 3060$ $\mathrm{m}$ asl. Scleronema operculatum: Brazil: Rio Grande do Sul: FMNH 58080, holotype of Scleronema operculatum Eigenmann, 1918, 65.1 mm SL, Cacequy. Scleronema sp.: Brazil: Rio Grande do Sul: MBUCV-V-32674, 2, 55.3-56.9 mm SL (1 CS, $55.3 \mathrm{~mm}$ $\mathrm{SL})$, rio São Sepé at lateral bridge to road BR-153, $c a .3 \mathrm{~km} \mathrm{~S}$

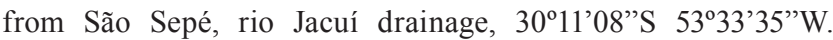
"Trichomycterus" hasemani: Brazil: Pará: FMNH 56424, holotype of Pygidium hasemani Eigenmann, 1914, $12.2 \mathrm{~mm}$ SL, Santarém. FMNH 56425, paratypes of Pygidium hasemani Eigenmann, 1914, 312 (not measured), same locality as FMNH 56424. Guyana: Siparuni: ANSP 175851, 3, 13.3-14.0 mm SL (1 $\mathrm{CS}, 13.2 \mathrm{~mm} \mathrm{SL}$ ), blackwater creek 5 minutes downstream from Burro Burro campsite, Siparuni VIII-2. Essequibo river basin: Rupununi: ANSP 179154, 2, 13.4 and $13.4 \mathrm{~mm} \mathrm{SL}$, Rupununi river, $3.7 \mathrm{~km}$ SSE village of Massara. "Trichomycterus" gr. hasemani sp. n. 1: Venezuela: Río Orinoco basin: Apure: MBUCV-V-19815, 4, 15.0-16.1 mm SL (1 CS, 15.7 mm SL), caño La Pica, tributary of río Capanaparo, where crossed by road between San Fernando de Apure and Puerto Páez. Amazonas: MCNG 38204, 4, 13.1-14.8 $\mathrm{mm}$ SL, Departamento Río Negro, río Manipitare, 5-8 km upriver from mouth of río Siapa. "Trichomycterus" gr. hasemani sp. n. 2: Venezuela: Río Orinoco basin: Amazonas: MCNG 42297, 1, $14.3 \mathrm{~mm}$ SL, Departamento Río Negro, río Pasimoni in Piedra Guamuribiti, 0141'02”N 66 32'48'W. Trichomycterus cf. kneri (sensu Eigenmann): Colombia: Río Orinoco basin: Casanare: IAvH-P 3787, 4, 81.1-103.7 mm SL (1 CS, 91.2 mm SL), Municipio Aguazul, quebrada NN, tributary of Caño Negro, llanos piedmont, río Meta drainage. Meta: IAvH-P 2741, 3, 39.8-40.6 mm SL, Municipio Villavicencio, caño Maizero, río Meta drainage, 0409'00"N 73³7'00”W. MPUJ 1960, 1, $50.7 \mathrm{~mm} \mathrm{SL}$, Municipio Villavicencio, caño Blanco in vereda El Carmen, $04^{\circ} 08^{\prime} 36.9^{\prime \prime} \mathrm{N}$ $73^{\circ} 40^{\prime} 22^{\prime \prime} \mathrm{W}, 1000 \mathrm{~m}$ asl. Trichomycterus rivulatus: Brazil: MCZ 8301, holotype of Trichomycterus eigenmanni Boulenger, 1898, 94.9 mm SL, Cumbaca. Peru: La Libertad: ANSP 22004, holotype of Trichomycterus pardus Cope, 1874, $58.6 \mathrm{~mm}$ SL, Jequetepeque. Trichomycterus tiraquae: Bolivia: Cochabamba: ANSP 69126, holotype of Pygidium tiraquae Fowler, 1940, $32.9 \mathrm{~mm}$ SL, Tiraque, $2743 \mathrm{~m}$ asl. ANSP 69127, paratypes of Pygidium tiraquae Fowler, 1940, 43, 20.9-30.5 mm SL, same locality as ANSP 69126. Trichomycterus spp.: Brazil: Santa Catarina: MCP 10649, 3, 52.9-84.2 mm SL (1 CS, 68.4 mm SL), rio Itapocu, Corupá, coastal system of south Brazil, 26 26'00"S 49¹5'00'W. São Paulo: MBUCV-V-32258, 2, 49.2-109.4 mm SL (1 CS, $49.2 \mathrm{~mm} \mathrm{SL}$ ), córrego do Benfica, tributary of rio Piquete, near from residence of Mr. Paulo Zacharias, Piquete, $22^{\circ} 35^{\prime} 00^{\prime \prime} \mathrm{S}$ $45^{\circ} 05^{\prime} 00^{\prime}$ W. Colombia: Río Magdalena basin: Boyacá: MPUJ 1952, 1, 31.6 mm SL, Municipio Cuítiva, quebrada El Gamse in vereda La Vega, tributary of río Chicamocha. MPUJ 1954, 1, $48.6 \mathrm{~mm} \mathrm{SL}$, Municipio Cuítiva, río Tota in vereda La Vega, at Hostería El Batán, río Chicamocha drainage, $2550 \mathrm{~m}$ asl. MPUJ 1955, 2, 31.1-46.6 mm SL, Municipio Cuítiva, río Tota in vereda La Vega, tributary of río Chicamocha, $2550 \mathrm{~m}$ asl. MPUJ 1956, 1, $79.8 \mathrm{~mm}$ SL, Municipio Cuítiva, río Tota in vereda La Vega, at Hostería El Batán, tributary of río Chicamocha, $2550 \mathrm{~m}$ asl. MPUJ 1957, 1, $54.8 \mathrm{~mm} \mathrm{SL}$, same locality as MPUJ 1956. MPUJ 1958, 2, 25.8-28.2 mm SL, Municipio Garagoa, Reserva El Secreto, vereda Ciénaga Valvanera, $2130 \mathrm{~m}$ asl. Cundinamarca: MPUJ 2494, 1, $31.0 \mathrm{~mm}$ SL, Municipio Suesca, cave in private property of Pedro Cintura, río Bogotá drainage, $05^{\circ} 06^{\prime} 00^{\prime \prime} \mathrm{N} 73^{\circ} 45^{\prime} 00^{\prime \prime} \mathrm{W}, 2799 \mathrm{~m}$ asl. Magdalena: MBUCV-V-29488, 1, $128.1 \mathrm{~mm} \mathrm{SL}$, quebrada Kemakumake, Sierra Nevada de Santa Marta. Santander: IAvH-P 4348, 1, $95.1 \mathrm{~mm}$ SL, Municipio Rionegro, río Santacruz in vereda San Jorge, río Lebrija drainage, $07^{\circ} 15^{\prime} 51.84^{\prime \prime} \mathrm{N} 73^{\circ} 08^{\prime} 58.92^{\prime} \mathrm{W}$, $590 \mathrm{~m}$ asl. Tolima: CZUT-IC 936, 2, 36.2-64.3 mm SL, Municipio Icononzo, quebrada Juan Lopitos, río Sumapáz drainage, 04¹0'59"N 74³2'29”W. Río Orinoco basin: Cundinamarca: IAvH-P 445, 1, $89.4 \mathrm{~mm}$ SL, Municipio Gachala, cueva La

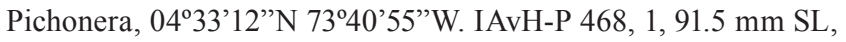
collected with IAvH-P 445. Río Patía basin: Cauca: IAvH-P 4739, 5, 76.1-114.7 mm SL (1 CS, $76.1 \mathrm{~mm} \mathrm{SL}$ ), Municipio Patía (El Bordo), quebrada Las Tallas, $02^{\circ} 06^{\prime} 00^{\prime} \mathrm{N} 77^{\circ} 03^{\prime} 00^{\prime} \mathrm{W}$. Nariño: 
CZUT-IC 1106, 1, 71.0 mm SL, río Esmite. Venezuela: Lago de Maracaibo basin: Zulia: EBRG 4774, 11, 31.9-89.9 mm SL (1 CS, $78.3 \mathrm{~mm} \mathrm{SL}$ ), Municipio Rosario de Perijá, caño tributary of río Lajas, in sector Yalomar, upper río Palmar drainage. Río Orinoco basin: Bolívar: MHNLS 14615, 36 (2 CS, 57.2-63.3 mm SL), Parque Nacional Canaima, río Churún-merú (headwaters); pool below Salto Angel, tributary of río Carrao, río Caroní drainage, 05'58'03"N 62'31'55". MHNLS 14909, 35 (2 CS, 52.9-65.8mm SL), same locality as MHNLS 14615. MHNLS 15720, 1, $75.2 \mathrm{~mm}$ SL, collected with MHNLS 14615. Sucre: MHNLS 14912, 1, 67.8 mm SL, Parque Nacional Península de Paria, first creek on the road from Puesto de Guardaparques Las Melenas to Cerro Humo, $10^{\circ} 39^{\prime} 00$ "N 62³4'00”W, $700 \mathrm{~m}$ asl.

\section{Acknowledgments}

W. Vanegas indicated the place where the new species was found. D. Galindo, A. Plata, S. Rengifo, and C. Rivera collaborated in the field trips. L. Ballesteros, T. Romero, and C. Molina assisted us in the laboratory. A. Urbano-Bonilla and J. Maldonado-Ocampo kindly provided the figure corresponding to the distribution map. The All Catfish Species Inventory Project (NSF DEB-0315963) funded visits of CD to LIRP and MZUSP in 2004. IAvH and Grupo de Investigaciones en Zoología of Universidad del Tolima funded CD visits to IAvH, CZUT, and MPUJ in 2005. Visit of CD to MZUSP in 2007 was partially funded by Facultad Experimental de Ciencias y Tecnología of Universidad de Carabobo. Visits of CD to ANSP and FMNH ichthyological collections in 2010 were possible through the Böhlke Memorial Endowment Fund and a Visitor Scholarship Grant, respectively. We are indebted to the following people and their respective institutions for hospitality during visits, loans of specimens and other assistance: J. Lundberg, M. Sabaj-Pérez and K. Luckenbill (ANSP), F. Villa-Navarro and L. García-Melo (CZUT), K. Swagel, M. A. Rogers, P. Willink and M Littmann (FMNH); J. Maldonado-Ocampo and J. Bogotá-Gregory (IAvH); J. Mojica and M. Arce (ICNMHN); F. Bockmann (LIRP); F. Provenzano (MBUCV); D. Taphorn and O. Castillo (MCNG); R. Reis (MCP); K. Hartel (MCZ); C. Lasso and O. Lasso-Alcalá (MHNLS); M. Azpelicueta (MLP); M. de Pinna, C. Moreira, M. I. Landim, F. Lima, A. Akama, N. Menezes, and O. Oyakawa (MZUSP). We also thank O. Villarreal-Manzanilla (MIZAUCV) for his generous assistance digitizing osteological sketches of figures 1-3, using the free software Inkscape. Special thanks are due to anonymous reviewer who provided helpful comments to improve diagnosis of the species.

\section{Literature Cited}

Adriaens, D., J. N. Baskin \& H. Coppens. 2010. Evolutionary morphology of trichomycterid catfishes: about hanging on and digging in. Pp. 337-362. In: Nelson, J. S., H.-P. Schultze \& M. V. H. Wilson (Eds.). Origin and Phylogenetic Interrelationships of Teleosts. München, Verlag Dr. Friedrich Pfeil.
Ardila Rodríguez, C. A. 2008. Trichomycterus cachiraensis (Siluriformes: Trichomycteridae), nueva especie del río Cachira, cuenca del río Magdalena, Colombia. Dahlia (Revista de la Asociación Colombiana de Ictiólogos), 10: 33-41.

Arratia, G. 1990. The South American Trichomycterinae (Teleostei: Siluriformes), a problematic group. Pp. 395-403. In: Peters, G. \& R. Hutterer (Eds.). Vertebrates in the tropics: Proceedings of the International Symposium on Vertebrate Biogeography and Systematics in the Tropics, Bonn, June 5-8, 1989, Bonn, Alexander Koenig Zoological Research Institute and Zoological Museum.

Arratia, G. 1998. Silvinichthys, a new genus of trichomycterid catfishes from the Argentinian Andes, with redescription of Trichomycterus nigricans. Ichthyological Exploration of Freshwaters, 9: 347-370.

Arratia, G., A. Chang, S. Menu-Marque \& G. Rojas. 1978. About Bullockia gen. nov., Trichomycterus mendozensis n. sp. and revision of the family Trichomycteridae (Pisces, Siluriformes). Studies on Neotropical Fauna and Environment, 13: 157-194.

Arratia, G. \& L. Huaquin. 1995. Morphology of the lateral line system and of the skin of diplomystid and certain primitive loricarioid catfishes and systematic and ecological considerations. Bonner Zoologische Monographien, 36: 1-110.

Arratia, G. \& S. Menu Marque. 1984. New catfishes of the genus Trichomycterus from the high Andes of South America (Pisces, Siluriformes) with remarks on distribution and ecology. Zoologische Jahrbücher, Systematik, 111: 493-520.

Arratia Fuentes, G. \& A. Chang Garrido. 1975. Osteocráneo de Nematogenys inermis Guichenot 1848 y consideraciones acerca de la primitividad del género (Peces Siluriformes, Trichomycteridae). Publicación Ocasional, Museo Nacional de Historia Natural, 19: 3-7.

Barbosa, M. A. \& W. J. E. M. Costa. 2003a. Trichomycterus potschi (Siluriformes: Loricarioidei): a new trichomycterid catfish from coastal streams of southeastern Brazil. Ichthyological Exploration of Freshwaters, 14: 281-287.

Barbosa, M. A. \& W. J. E. M. Costa. 2003b. Validade, relações filogenéticas e redescrição de Eremophilus candidus Ribeiro, 1949 (Teleostei, Siluriformes, Trichomycteridae). Arquivos do Museu Nacional, 61: 179-188.

Baskin, J. N. 1973. Structure and relationships of the Trichomycteridae. Unpublished Ph.D. Dissertation, City University of New York, New York.

Bichuette, M. E., M. C. C. de Pinna \& E. Trajano. 2008. A new species of Glaphyropoma: the first subterranean copionodontine catfish and the first occurrence of opercular odontodes in the subfamily (Siluriformes: Trichomycteridae). Neotropical Ichthyology, 6: 301-306.

Bockmann, F. A., L. Casatti \& M. C. C. de Pinna. 2004. A new species of trichomycterid catfish from the Rio Paranapanema basin, southeastern Brazil (Teleostei: Siluriformes), with comments on the phylogeny of the family. Ichthyological Exploration of Freshwaters, 15: 225-242.

Castellanos-Morales, C. A. 2011 (2010). Trichomycterus sketi: a new species of subterranean catfish (Siluriformes: Trichomycteridae) from the Andean Cordillera of Colombia. Biota Colombiana 11: 33-41.

Castellanos-Morales, C. A. \& F. Galvis. 2012. Las especies del género Trichomycterus (Siluriformes: Trichomycteridae) en Colombia. Boletín Científico Centro de Museos Museo de Historia Natural, 16: 194-206. 
Costa, W. J. E. M. \& F. A. Bockmann. 1993. Un nouveau genre néotropical de la famille des Trichomycteridae (Siluriformes: Loricarioidei). Revue Française d'Aquariologie et Herpetologie, 20: 43-46.

Datovo, A. \& F. A. Bockmann. 2010. Dorsolateral head muscles of the catfish families Nematogenyidae and Trichomycteridae (Siluriformes: Loricarioidei): comparative anatomy and phylogenetic analysis. Neotropical Ichthyology, 8: 193-246.

DoNascimiento, C., S. Prada-Pedreros \& J. Guerrero-Kommritz. 2014. Trichomycterus venulosus (Steindachner, 1915), a junior synonym of Eremophilus mutisii Humboldt, 1805 (Siluriformes: Trichomycteridae) and not an extinct species. Neotropical Ichthyology, 12(4).

Eigenmann, C. H. 1918. The Pygidiidae, a subfamily of South American catfishes. Memoirs of the Carnegie Museum, 7: 259398.

Eschmeyer, W. N. (ed). Genera, species, references. Available from: http://research.calacademy.org/research/ichthyology/ catalog/fishcatmain.asp. (10 Jan 2014).

Fernández, L. \& K. Osinaga. 2006. A new Trichomycterus (Siluriformes: Trichomycteridae) from Aguarague National Park of the Bolivian preandean region, with comments on the relationships within the genus. Environmental Biology of Fishes, 75: 385-393.

Fernández, L. \& R. Quispe Chuquihuamaní. 2007. A new species of Trichomycterus (Siluriformes: Trichomycteridae) from the Andean Cordillera of Perú, with comments on relationships within the genus. Zootaxa, 1545: 49-57.

Ferrer, J. \& L. R. Malabarba. 2013. Taxonomic review of the genus Trichomycterus Valenciennes (Siluriformes: Trichomycteridae) from the laguna dos Patos system, Southern Brazil. Neotropical Ichthyology, 11: 217-246.

Leviton, A. E., R. H. Gibbs Jr., E. Heal \& C. E. Dawson. 1985. Standards in herpetology and ichthyology. Part. 1. Standard symbolic codes for institutional resource collections in herpetology and ichthyology. Copeia, 1985: 802-832.

Lundberg, J. G. 2005. Brachyplatystoma promagdalena n. sp., a fossil goliath catfish (Siluriformes: Pimelodidae) from the Miocene of Colombia, South America. Neotropical Ichthyology, 3: 597-605.

Lundberg, J. G. \& J. N. Baskin. 1969. The caudal skeleton of the catfishes, Order Siluriformes. American Museum Novitates, 2398: 1-49.

Maldonado-Ocampo, J. A., R. P. Vari \& J. Saulo Usma. 2009 (2008). Checklist of the freshwater fishes of Colombia. Biota Colombiana 9: 143-237.

Morris, P. J., Yager, H. M. \& Sabaj Pérez, M. H. 2006. ACSImagebase: a digital archive of catfish images compiled by participants in the All Catfish Species Inventory. [WWW image Database] Available from: http://acsi.acnatsci.org/base. de Pinna, M. C. C. 1989. A new sarcoglanidine catfish, phylogeny of its subfamily, and an appraisal of the phyletic status of the Trichomycterinae (Teleostei, Trichomycteridae). American Museum Novitates, 2950: 1-25.

de Pinna, M. C. C. 1992a. Trichomycterus castroi, a new species of trichomycterid catfish from the Rio Iguaçu of Southeastern Brazil (Teleostei: Siluriformes). Ichthyological Exploration of Freshwaters, 3: 89-95.

de Pinna, M. C. C. 1992b. A new subfamily of Trichomycteridae (Teleostei, Siluriformes), lower loricarioid relationships and a discussion on the impact of additional taxa for phylogenetic analysis. Zoological Journal of the Linnean Society, 106: 175-229.

de Pinna, M. C. C. 1998. Phylogenetic relationships of Neotropical Siluriformes (Teleostei: Ostariophysi): historical overview and synthesis of hypotheses. Pp. 279-330. In: Malabarba, L. R., R. E. Reis, R. P. Vari, Z. M. S. Lucena \& C. A. S. Lucena (Eds.). Phylogeny and Classification of Neotropical Fishes. Porto Alegre, Edipucrs.

de Pinna, M. C. C., J. L. Helmer, H. A. Britski \& L. Rodrigues Nunes. 2010. A new species of Trichogenes from the rio Itapemirim drainage, southeastern Brazil, with comments on the monophyly of the genus (Siluriformes: Trichomycteridae). Neotropical Ichthyology, 8: 707-717.

Schaefer, S. A. 2003. Relationships of Lithogenes villosus Eigenmann, 1909 (Siluriformes, Loricariidae): evidence from high-resolution computed microtomography. American Museum Novitates, 3401: 1-55.

Schaefer, S. A. \& A. E. Aquino. 2000. Postotic laterosensory canal and pterotic branch homology in catfishes. Journal of Morphology, 246: 212-227.

Schaefer, S. A. \& L. Fernández. 2009. Redescription of the pez graso, Rhizosomichthys totae (Trichomycteridae), of Lago de Tota, Colombia, and aspects of cranial osteology revealed by microtomography. Copeia, 2009: 510-522.

Taylor, W. R. \& G. C. Van Dyke. 1985. Revised procedures for staining and clearing small fishes and other vertebrates for bone and cartilage study. Cybium, 9: 107-119.

Wosiacki, W. B. \& M. C. C. de Pinna. 2008. Trichomycterus igobi, a new catfish species from the rio Iguaçu drainage: the largest head in Trichomycteridae (Siluriformes: Trichomycteridae). Neotropical Ichthyology, 6: 17-23.

Wosiacki, W. B. \& J. C. Garavello. 2004. Five new species of Trichomycterus from the rio Iguaçu (rio Paraná Basin), southern Brazil (Siluriformes: Trichomycteridae). Ichthyological Exploration of Freshwaters, 15: 1-16.

Submitted January 10, 2014 Accepted June 19, 2014 by Marcelo R. Britto Published December 27, 2014 